\title{
COMMENT
}

\section{Higher education and non-violent civil disobedience}

\author{
Jon Rosales* \\ Environmental Studies, St. Lawrence University, Canton, New York 13617, USA
}

J. Lemons and D. A. Brown, 2 admittedly timid scholars, pose the question of whether non-violent civil disobedience is now ethically justified in the case of climate change (Lemons \& Brown 2011, this issue).

In order to get to a position where an individual must decide on whether non-violent civil disobedience is in fact justified and necessary, what can be called an 'I gotta do something' moment, one must first see themselves clearly, especially in relation to others, so as to be impelled to act. The role of higher education is paramount in developing the self-vision required for individuals to arrive at the 'I gotta do something' moment. This is why universities, where young people explore who they are and what they value, are hotbeds of civil disobedience.

A curricular strategy built around the concept of positionality compels the self-reflection necessary for students to see themselves clearly and perhaps arrive at an 'I gotta do something' moment.

Positionality is the practice of recognizing one's own position - gender, social status, race, sexuality, and so forth - and its relation to other beings and things, including the planet. Positionality refers to the recognition that position in life often determines one's production of knowledge. Positionality often avoids solipsism, i.e. the tendency toward discounting, or not acknowledging at all, any experience other than your own. Solipsism should be avoided because it discourages seeing the conditions of others and being empathetic; solipsism encourages being aloof to injustice.

If, however, we are to resolve the climate crisis and 'swerve', as eminent science studies scholar Donna Haraway states, 'from the established disorder of finished, deadly worlds,' we must first be able to recognize the deadly conditions our existence creates (Haraway 1994, p. 66). Those of us who reside in cultures of high consumption must recognize the repercussions of a high consumption lifestyle and how our existence affects others outside our experience. We must, for example, recognize the ravages of climate change on peoples in far off lands such as Tuvalu, the Maldives, and in coastal Alaska.

A curriculum based on positionality would quickly reveal that wealthier peoples are largely to blame for climate chaos because of the higher consumption that usually accompanies wealth and that those of us in positions of privilege have the duty to act first and shoulder the burden for climate action. By extension, people living a privileged life have the ethical responsibility to work for change. This ethical reasoning again brings us to answer the question posed by Lemons \& Brown (2011): Is non-violent civil disobedience ethically justified in the case of climate change? Yes, especially for those who possess the unfortunate facts about climate change and their society's contribution to the crisis, and who understand that greenhouse gas emissions anywhere threaten life everywhere.

The privileged few, like Lemons and Brown, can use non-violent civil disobedience to make these facts visible, create the tension necessary for these facts to be confronted, and to avoid, in the words of Martin Luther King (King 1963, p. 3), the 'appalling silence' and indifference of the majority.

King (1963) recommends a 4 step process for civil disobedience, which is also the logical extension of a curriculum based on positionality: (1) Collection of facts: find out where injustice resides and expose it. (2) Negotiation: try to resolve tensions through dialogue. If these fail, (3) self-purification: prepare yourself for the repercussions of your actions - ask yourself if you can 'accept blows without retaliating'; then (4) direct action: publically present yourself in opposition to injustice.

The facts on climate change were submitted long ago. The science of climate change and its dire impacts 
have been known to us in the climate change community since at least the 1980s. Further, beginning at the Earth Summit in 1992, governments have negotiated climate policy for 18 years. 'Justice too long delayed is justice denied' (King 1963, p. 2). It is time for non-violent civil disobedience. As environmental philosopher Bill Vitek says, what must be done is akin to 'yelling, "Fire!" in a crowded theater when there is, in fact, a fire.' (Vitek 2008, p. 16).

When the injustice that creates a deadly world continues and is institutionalized, 'when,' as Henry David Thoreau says, 'the friction comes to have its machine,' (Thoreau 1849, p. 4) it is time to be an extremist for justice. Some issues are worth the disruption and disobedience. Surely, we have more to lose from the ravages of climate change than what personal fate we might experience from civil disobedience.

As educators we must make sure our actions and the actions of our students are based on the facts and that earnest negotiation has run its course. Then, filter out 'pious irrelevancies and sanctimonious trivialities,' as

Editorial responsibility: Darryl Macer,

Bangkok, Thailand
King (1963, p. 4) says, in order to see clearly. If then our students come to an 'I gotta do something' moment, they can be assured it is the right thing to do.

This is how positionality can avoid solipsism. Institutions of higher education are the most obvious sites to employ this work.

\section{LITERATURE CITED}

Haraway DJ (1994) A game of cat's cradle: science studies, feminist theory, cultural ctudies. Configurations 2:59-71

King ML Jr (1963) Letter from a Birmingham jail. African Studies Center, University of Pennsylvania, PA. Available at: www.africa.upenn.edu/Articles_Gen/Letter_Birmingham.html

Lemons J, Brown DA (2011) Global climate change and non-violent civil disobedience. Ethics Sci Environ Polit 11: $3-12$

Thoreau HD (1849) Resistance to civil government (civil disobedience). Classic Books, New York, NY

Vitek B (2008) These revolutionary times. The Land Report 91:13-17. Available at http://people.clarkson.edu/ wvitek/ landreport.pdf

Submitted: 30 November 2010; Accepted: February 15, 2011 Proofs received from author(s): March 31, 2011 